ANDRZEJ ŁUKASIK (D) orcid.org/0000-0002-5338-2570

Zakład Psychologii, Uniwersytet Rzeszowski Department of Psychology, University of Rzeszów e-mail: and.lukasik@gmail.com

DOMINIK BORAWSKI (D) orcid.org/0000-0002-1504-2145 Instytut Pedagogiki i Psychologii, Uniwersytet Jana Kochanowskiego, Kielce Institute of Pedagogy and Psychology, Jan Kochanowski University, Kielce e-mail:dborawski@ujk.edu.pl

ANNA WOŁPIUK-OCHOCIŃSKA (D) orcid.org/0000-0002-4316-7308

Department of Psychology, University of Rzeszów Zakład Psychologii, Uniwersytet Rzeszowski e-mail: annawolpiuk@o2.pl

\title{
Cechy osobowości jako mediator między strategiami reprodukcyjnymi związanymi z historią życia a światopoglądem. Moderacyjna rola płci
}

\section{Personality Traits as a Mediator between Reproductive Life History Strategies and Worldview. The Moderating Role of Sex}

\begin{abstract}
With regard to human, life history theory postulates the existence of a continuum of reproductive life history strategies (LHS): fast strategy-slow strategy. Earlier studies show that the personality dimensions of the Big Five and worldview are correlated with LHS. In the present study we tested the hypothesis that the dimensions of the Big Five are mediators between LHS and worldview. Structural equation modeling (SEM) was used to test the model in a sample of 259 participants; additionally, the moderating role of the sex variable was included. In accordance with the hypothesis, the dimensions of the Big Five turned out to be mediators between LHS and worldview. The analysis of moderated mediation showed a significant role of the sex variable in the tested model. According to the assumptions of life history theory, this indicates the role of early childhood experiences in shaping the worldview, however, the role of sex in relation to the diversity of these experiences and their impact on shaping reproductive strategies requires further research.
\end{abstract}

Keywords: life history strategies, Big Five, life history, worldview.

Słowa kluczowe: strategie reprodukcyjne, wielka piątka, historia życia, światopogląd. 


\section{WPROWADZENIE}

Cechą charakterystyczną naszego gatunku jest wydłużony okres dzieciństwa, który wiąże się z zależnością od opieki matki bezpośrednio po urodzeniu oraz długo po okresie karmienia piersią (Hochberg, 2011). Ewolucyjna psychologia rozwojowa zakłada, że wydłużone dzieciństwo u naszego gatunku jest niezbędne do nabycia kompetencji potrzebnych do funkcjonowania w złożonym świecie społecznym (Machluf, Liddle, Bjorklund, 2014). W okresie dzieciństwa rozwijają się tak zwane adaptacje warunkowe (conditional adaptations), których zadaniem jest wykrycie określonych cech środowiska i - stosownie do nich - ukierunkowanie rozwoju (Machluf, Bjorklund, 2015). Jedną z ważniejszych współczesnych teorii ewolucyjnych podkreślających centralną rolę środowiska w powstawaniu adaptacji warunkowych oraz ukierunkowaniu rozwoju jest teoria historii życia (life history theory - LHT; Gadgil, Bossert, 1970; Stearns, 1992). Zgodnie z nią - w przypadku człowieka określone czynniki środowiskowe i społeczne we wczesnym dzieciństwie są dla organizmu wskazówkami dotyczącymi tego, jaka strategia reprodukcyjna (czyli jakie zachowania i cechy psychofizyczne służące zdobyciu i utrzymaniu partnera oraz pozostawieniu po sobie potomstwa) będzie dla niego optymalna (Belsky, Steinberg, Draper, 1991; Del Giudice, Belsky, 2011; zob. też Barbaro, Boutwell, Barnes, Shackelford, 2017). W ten sposób ewolucyjna psychologia rozwojowa wpisuje się w szerszy kontekst badań psychologii rozwojowej związanych z odpowiedzią na pytanie, czy i w jaki sposób różnego rodzaju doświadczenia wczesnodziecięce (np. sensytywność rodzicielska) determinują późniejszy rozwój cech osobowości, a także rozwój społeczny i poznawczy (np. Beaver, Hartman, Belsky, 2015; Raby, Roisman, Fraley, Simpson, 2015; Fraley, Roisman, Haltigan, 2013).

Z określonymi strategiami reprodukcyjnymi kształtowanymi przez historię życia powiązane są cechy osobowości (Alvergne, Jokela, Lummaa, 2010; Figueredo, Vásquez, Brumbach, Schneider, 2004). W psychologii ewolucyjnej osobowość jest traktowana jako forma biologicznej adaptacji (Buss, 1991; Simpson, Gri- skevicius, Kim, 2011) służącej dostosowaniu: przetrwaniu i pozostawieniu po sobie potomstwa. Różnice indywidualne w zakresie cech osobowościowych odzwierciedlają różnice między ludźmi w strategiach rozwiązywania społecznych problemów adaptacyjnych (tzn. takich, które stanowiły w ewolucyjnej przeszłości i nadal stanowią istotny problem dla dostosowania), na przykład uzyskania statusu czy pozyskania zasobów (Buss, 2009). Podkreśla się, że LHT może być użyteczną ramą teoretyczną dla testowania hipotez o związkach między osobowością a dostosowaniem i różnicami indywidualnymi w zakresie wymiarów osobowości (Nettle, 2005).

Wykazano także, że ze strategiami reprodukcyjnymi jest powiązany światopogląd rozumiany jako przekonania na temat świata ( $\mathrm{Ku}-$ kasik, Wołpiuk-Ochocińska, Borawski, 2018). Światopogląd ma związek z zachowaniami charakteryzującymi strategie reprodukcyjne, na przykład religijność odracza inicjację seksualną dziewcząt (Rostosky, Wilcox, Wright, Randall, 2004) i zmniejsza częstość różnych zachowań seksualnych (Penhollow, Young, Denny, 2005). Światopogląd to zestaw przekonań i założeń, które opisują rzeczywistość, w tym naturę ludzką, znaczenie i naturę życia oraz budowę wszechświata (Koltko-Rivera, 2004). Ponadto światopogląd angażuje wszystkie sfery funkcjonowania człowieka. Powinien być zatem rozpatrywany nie tylko jako struktura poznawcza, ale również w kontekście osobowości i zachowania (Cieciuch, 2005, s. 105). Szczególną rolę przypisuje się światopoglądowi w integracyjnym podejściu do osobowości nazywanym nieredukcyjnym materializmem (non-reductive materialism) (Nilsson, 2014a, 2014b). Osoba (person) poszukuje znaczenia w świecie i każde jej działanie nasycone jest znaczeniem: światopogląd dostarcza ram semantycznych dla ludzkich działań (Nilsson, 2014a). Oprócz centralnej roli światopoglądu w omawianym podejściu postuluje się, że psychologia osobowości powinna poszukiwać związków między cechami osobowości a światopoglądem: „włączyć zarówno badania cech i badania światopoglądu, jako wzajemnie nieredukowalnych i równie podstawowych części osobowości" (Nilsson, 2014a, s. 29; zob. 
też Nilsson, 2014b). Należy podkreślić, że do tej pory badano związki między cechami osobowości a światopoglądem głównie w kontekście postaw politycznych (np. Hirsh, DeYoung, Xiaowen, Peterson, 2010) czy religijnych (np. Wilt, Grubbs, Exline, Pargament, 2016). Brak natomiast badań, które odnosiłyby się do bardziej podstawowego światopoglądu dotyczącego fundamentalnych przekonań na temat świata.

\section{Teoria historii życia}

Teoria historii życia (life history theory - LHT) zakłada, że strategie reprodukcyjne związane z historią życia (life history strategy - LHS) polegają na alokacji (trade-off) zasobów materialnych i bioenergetycznych organizmu (Gadgil, Bossert, 1970). Dwa podstawowe kierunki alokacji to wysiłek somatyczny (somatic effort) związany z przeżyciem organizmu (np. podtrzymanie funkcji życiowych), a także - w przypadku człowiekazdobycie wiedzy, wykształcenia czy umiejętności, oraz wysiłek reprodukcyjny (reproductive effort) związany z nakładami na reprodukcję (Del Giudice, Belsky, 2011; Figueredo i in., 2006; Griskevicius, Tybur, Delton, Robertson, 2011). Wysiłek reprodukcyjny składa się z kolei z wysiłku skierowanego na partnera (mating effort) - przyciągnięcie i utrzymanie partnera (np. rywalizacja intraseksualna, a w przypadku człowieka np. taktyki utrzymania partnera w związku, zazdrość), wysiłku rodzicielskiego (parental effort) - związanego z nakładami na posiadanie potomstwa, opiekę, jego ochronę, oraz wysiłku skierowanego na krewnych (nepotistic effort), gdy celem staje się pomoc osobom powiązanym genetycznie (oprócz własnego dziecka). Duży wysiłek skierowany na partnera reprezentuje tak zwaną szybką strategię reprodukcyjną, wysoki wysiłek somatyczny i wysiłek rodzicielski zaś reprezentują wolną strategię (Figueredo, Cuthbertson, Kauffman, Weil, Gladden, 2012; Griskevicius i in., 2011). Strategia wolna wiąże się między innymi z dużymi nakładami rodzicielskimi, skłonnością do związków długotrwałych, opóźnionym dojrzewaniem seksualnym, orientacją na przyszłość, zdolnością do odraczania gratyfikacji, mniej antagonistycznymi zachowaniami i postawami typu wrogość, nieufność, podejrzli- wość, niższym poziomem agresji interpersonalnej, strategia szybka zaś - z niskimi nakładami rodzicielskimi, skłonnością do związków krótkotrwałych, przyspieszonym rozwojem seksualnym, orientacją na ,tu i teraz”, ze słabszą kontrolą agresji interpersonalnej i skierowanej na partnera, zewnętrznym poczuciem kontroli (LOC), z wyższym natężeniem cech należących do ciemnej triady, zachowań ryzykownych (Csathó, Birkás, 2018; Figueredo, Cabeza de Baca, Woodley, 2013; Figueredo i in., 2018; Gladden, Figueredo, Snyder, 2010; Jonason, Webster, Schmitt, Li, Crysel, 2012; Mell, Safra, Alganb, Baumard, Chevallier, 2017; Nettle, 2010; Peterson, Geher, Kaufman, 2011; Rucas, Miller, 2013; Wenner, Bianchi, Figueredo, Rushton, Jacobs, 2013). Strategie reprodukcyjne związane z historią życia są wrażliwe na różne wskazówki środowiskowe świadczące o nieprzyjazności (harsheness) środowiska lub nieprzewidywalności zachodzących w nim zmian, na przykład wskaźnik zachorowalności/śmiertelności w obecnym środowisku lub ograniczoność zasobów (Chang, Lu, 2018; Griskevicius i in., 2011; Griskevicius i in., 2013).

Teoria historii życia znalazła zastosowanie w psychologii rozwojowej. Patricia Draper i Henry Harpending (1982) postawili hipotezę, że w przypadku dziewcząt nieobecność ojca we wczesnym dzieciństwie jest sygnałem, iż nie należy spodziewać się wysokich nakładów rodzicielskich ze strony przyszłego partnera. Prowadzi to z kolei do strategii reprodukcyjnej, którą charakteryzuje wczesne rozpoczęcie aktywności seksualnej i budowanie niestabilnych związków. Na tej podstawie Jay Belsky, Laurence Steinberg i Patricia Draper (1991) dokonali integracji tradycyjnych teorii rozwojowych, takich jak teoria przywiązania, teoria uczenia społecznego z teorią historii życia w postaci teorii socjalizacji, a w obecnej bardziej rozwiniętej formie znanej pod nazwą teorii akceleracji psychospołecznej (psychosocial acceleration theory) (Ellis, 2004). W teorii tej zakłada się, że czynniki świadczące o sposobie funkcjonowania rodziny, takie jak relacja rodzice-dzieci czy relacje między rodzicami, określają wybór strategii reprodukcyjnej. Ponadto teoria zakłada, że istnieją dwie podstawowe ścieżki rozwoju, a okres sensytywny dla ich rozwoju to pierw- 
sze 5-7 lat życia. Pierwsza ścieżka, od konfliktów wewnątrzrodzinnych, nieprzyjazności środowiska poprzez odrzucający lub niespójny styl wychowania wiedzie do pozabezpiecznych stylów przywiązania i w konsekwencji przyspieszonego rozwoju psychoseksualnego. Jego skutkiem jest szybka strategia reprodukcyjna. Druga ścieżka, od harmonii między małżonkami poprzez sensytywne i wspierające rodzicielstwo wiedzie do bezpiecznego stylu przywiązania, a w konsekwencji do opóźnionego rozwoju psychoseksualnego. Jego skutkiem jest $\mathrm{z}$ kolei wolna strategia reprodukcyjna.

\section{Wymiary wielkiej piątki a strategie reprodukcyjne związane $z$ historią życia}

W psychologii ewolucyjnej ujmuje się osobowość jako the adaptive landscape, to znaczy zestaw mechanizmów psychologicznych o biologicznym znaczeniu, które pomagały naszym przodkom przeżyć i się reprodukować (Buss, 1991; Simpson i in., 2011).

W ramach teorii historii życia cechy osobowości traktuje się jako mediatory między czynnikami kształtującymi strategię (np. wczesne środowisko) a określonymi trajektoriami strategii reprodukcyjnych związanych $\mathrm{z}$ historią życia (np. stabilność związków romantycznych) (Copping, Campbell, Muncer, 2014) bądź jako korelaty lub wskaźniki strategii reprodukcyjnej (Figueredo i in., 2006). Cechy osobowości są kształtowane w pewnym zakresie przez doświadczenia wczesnodziecięce w sposób podobny jak strategie reprodukcyjne związane z historią życia (Csható, Birkás, 2018).

W psychologii ewolucyjnej wymiary wielkiej piątki są opisywane jako efekt przetargu (trade off) między kosztami a zyskami w kategoriach dostosowania (fitness costs and benefits) (Nettle, 2005, 2006; zob. także Jokela, Alvergne, Pollet, Lummaa, 2011; van Leeuwen, Mace, 2016). Dla przykładu, zgodnie z tą propozycją sumienność to $z$ jednej strony możliwość osiągania odległych celów i samokontrola, ale z drugiej strony ryzyko zmniejszenia sukcesu reprodukcyjnego poprzez utratę spontaniczności w relacjach z płcią przeciwną i mniejszą liczbę krótkotrwałych epizodów reprodukcyjnych (Nettle, 2006).
Sumienność, ugodowość, stabilność emocjonalna (rozumiana jako odwrotność neurotyzmu) wiążą się z preferencją związków długotrwałych nad krótkotrwałymi (Banai, Pavela, 2015; Holtzman, Strube, 2013). Manson (2015) stwierdził w odniesieniu do 6-czynnikowego modelu osobowości (HEXACO), że osoby o wolnej strategii reprodukcyjnej są bardziej sumienne, ugodowe i ekstrawertywne. Stwierdzono także negatywną korelację neurotyczności z wolną strategią reprodukcyjną (Figueredo, Vásquez, Brumbach, Schneider, 2004; Figueredo i in., 2006; Gladden, Figueredo, Jacobs, 2009). W odniesieniu do otwartości na doświadczenie wykazano pozytywną korelację z wolną strategią reprodukcyjną (Gladden i in., 2009), podobnie w przypadku ekstrawersji (Gladden $\mathrm{i}$ in., 2009; Manson, 2015).

\section{Strategie reprodukcyjne związane $z$ historią życia a światopogląd}

Jednostki rozwijają przekonania na temat siebie i świata, które są fundamentalne dla zdrowego funkcjonowania (Janoff-Bulman, 1992). Najważniejsze spośród nich to przekonanie o sprawiedliwym, życzliwym, przewidywalnym świecie oraz kompetentnym i wartościowym ja. Te przekonania są formowane we wczesnym dzieciństwie poprzez interakcję z opiekunem (Janoff-Bulman, 1992). Wykazano, że osoby o wolnej strategii reprodukcyjnej mają bardziej pozytywne przekonania zarówno na temat otaczającego świata, jak i własnej osoby (Lukasik i in., 2018). Wolna strategia reprodukcyjna rozwija schematy społeczne oparte na współpracy, szybka LHS zaś promuje rozwój schematów antagonistycznych (Figueredo, Jacobs, 2010; Figueredo i in., 2018), ideologię rewanżu (Figueredo, Gladden, Beck, 2010), negatywny etnocentryzm (Figueredo, Andrzejczak, Jones, Smith-Castro, Montero, 2011) i negatywny androcentryzm (Gladden, Figueredo, Andrzejczak, Jones, Smith-Castro, 2013).

\section{Osobowość a światopogląd}

Teoretyczny grunt do ujmowania wzajemnych relacji pomiędzy osobowością a światopoglądem mogą stanowić teorie osobowości, w których zestawia się właściwości dyspozycyjne 
z różnymi zmiennymi poznawczo-motywacyjnymi określanymi mianem charakterystycznych adaptacji (McCrae, Costa, 1999; McCrae i in., 2000; McAdams, Pals, 2006). Charakterystyczne adaptacje, wyrażane między innymi przez motywy, cele, plany, wartości, strategie radzenia sobie, a także poznawcze reprezentacje siebie i innych, stanowią aktywną stronę osobowości, która kształtuje się na bazie podstawowych właściwości strukturalnych osobowości opisanych m.in. w ramach teorii wielkiej piątki. W świetle tego ujęcia przekonania na temat świata jako charakterystyczne adaptacje są wtórne wobec biologicznie uwarunkowanych zrębów osobowości i w większym stopniu niż one podlegają wpływom środowiskowym i kulturowym (por. McCrae, Costa, 1999; McAdams, Olson, 2010).

Jedyne znane nam badania, w których przedstawiono związki cech wielkiej piątki z przekonaniami operacjonalizowanymi w taki sam sposób jak w niniejszym badaniu, dotyczyły tylko przekonań o życzliwości świata i wykazały słabe korelacje dodatnie z ugodowością, sumiennością, otwartością na doświadczenie i ekstrawersją oraz korelację ujemną z neurotycznością (Poulin, Silver, 2008). Pewne dane pozwalają jednak przewidywać związki pomiędzy wymiarami wielkiej piątki a przekonaniem o sensowności świata. Badania nad pokrewnymi zmiennymi (takimi jak przekonanie o sprawiedliwości świata, poczucie koherencji czy wiara w wynagradzanie wysiłku) sugerują, że pozytywnymi predyktorami postrzegania świata jako sensownego, zrozumiałego i sprawiedliwego są ekstrawersja, ugodowość i sumienność, natomiast negatywnym predyktorem - neurotyczność (por. Nudelman, 2013; Chen, Fok, Bond, Matsumoto, 2006; Grevenstein, Bluemke, 2015). Z kolei otwartość na doświadczenie jest dodatnio skorelowana z przekonaniem o złożoności świata społecznego (Chen i in., 2006). Każdy z wymiarów wielkiej piątki koreluje dodatnio ze zmiennymi wyrażającymi wartościowanie własnej osoby - takimi jak samoocena czy przekonanie o własnej skuteczności (Robins, Tracy, Trzesniewski, Potter, Gosling, 2001; Watson, Suls, Haig, 2002; Judge, Jackson, Shaw, Scott, Rich, 2007; Erdle, Gosling, Potter, 2009; Sharpe, Martin, Roth, 2011).

\section{HIPOTEZY BADAWCZE}

Zgodnie z poglądem prezentowanym przez autorów teorii wielkiej piątki (McCrae, Costa, 1999; McCrae i in., 2000) zakładamy, że wymiary wielkiej piątki jako uwarunkowane biologicznie są pierwotne w stosunku do światopoglądu kształtującego się pod wpływem czynników społecznych. Z przeglądu badań z zakresu psychologii ewolucyjnej wynikają następujące hipotezy: 1) wolna strategia reprodukcyjna jest związana $z$ pozytywnym obrazem świata i siebie; 2) wolna strategia reprodukcyjna jest związana ze stabilnością emocjonalną, ugodowością i sumiennością, ekstrawersją i otwartością na doświadczenie; 3) mediatorem między wolną strategią reprodukcyjną a światopoglądem są wymiary osobowości: stabilność emocjonalna, ugodowość i sumienność, otwartość na doświadczenie i ekstrawersja; każdy z tych wymiarów koreluje pozytywnie zarówno z wolną strategią reprodukcyjną, jak i trzema aspektami światopoglądu.

\section{METODA}

\section{Grupa badana}

Zwrot arkuszy badawczych uzyskano od 259 osób. Do analizy nie włączono jednak danych, w których brakowało ponad 50\% odpowiedzi (10 osób) oraz obserwacji odstających (outliers) zgodnie $\mathrm{z}$ miarą odległości Mahalanobisa (5 osób). Analizie statystycznej poddano tym samym dane pochodzące od 244 osób w wieku między 18. a 53. rokiem życia $(M=27.25, S D=7.53)$. $\mathrm{W}$ grupie badanej dominowały kobiety (75\%). Nieco ponad $52 \%$ badanych zamieszkiwało wsie (44\%) i małe miasta liczące do 10 tys. mieszkańców (12\%), 26,4\% badanych mieszkało w średnich miastach, a 17,4\% - w dużych miastach powyżej 100 tys. mieszkańców. Badani byli zróżnicowani pod względem wykształcenia: najliczniejszą grupę stanowiły osoby $\mathrm{z}$ wykształceniem średnim $(51,2 \%)$ oraz wyższym $(44,2 \%)$, najmniej liczni byli badani z wykształceniem podstawowym (1 osoba) i zawodowym (5\%).

Projekt badań został zaakceptowany przez lokalną komisję bioetyczną. 


\section{Procedura badania}

Uczestnicy samodzielnie wypełnili zestaw narzędzi opisanych poniżej. Badanie było anonimowe. Wszyscy uczestnicy zostali osobiście poinformowani o warunkach i procedurze badania oraz udzielili świadomej zgody na udział w badaniu.

\section{Narzędzia badawcze}

\section{Strategia reprodukcyjna zwiazana z historia życia}

Do pomiaru strategii reprodukcyjnej (LHS) wykorzystano polską wersję skali ALHB (The Arizona Life History Battery) (Figueredo i in., 2006) w adaptacji Anny Czarnej (Jonason, Cheng, Li, Czarna, 2013). ALHB mierzy poznawcze i behawioralne wyznaczniki strategii reprodukcyjnej, które składają się na tak zwany czynnik K opisujący strategię reprodukcyjną na kontinuum ,szybka - wolna”. Bateria składa się z 7 podskal: Wgląd, planowanie, kontrola (20 itemów), Relacje z Matką/Ojcem (26 itemów), Relacje rodzinne i wsparcie (15 itemów), Relacje z przyjaciółmi i wsparcie (15 itemów), Doświadczenia w bliskich związkach (36 itemów), Altruizm (50 itemów) i Religijność (17 itemów). Osoba badana określa na skali Likerta (od $-3=$ Zupetnie się nie zgadzam do 3 = Zupetnie się zgadzam $)$ lub $(0=$ Wcale, $w$ ogóle nie do $3=$ Bardzo), w jakim stopniu zgadza się z poszczególnymi stwierdzeniami. Im wyższy wynik, tym wyższy wskaźnik wolnej strategii reprodukcyjnej. Wartości psychometryczne polskiej wersji ALHB są satysfakcjonujące (tabela1).

\section{Osobowość (wielka piątka)}

Inwentarz TIPI-PL (Sorokowska, Słowińska, Zbieg, Sorokowski, 2014) jest polską adaptacją Ten-Item Personality Inventory (TIPI) (Gosling, Rentfrow, Swann Jr., 2003). TIPI-PL służy do pomiaru cech osobowości ujmowanych w modelu wielkiej piątki (neurotyczność, ekstrawersja, sumienność, otwartość na doświadczenie oraz ugodowość (Costa, McCrae, 1992; John, Srivastava, 1999). Polska wersja składa się z 10 stwierdzeń rozpoczynających się od słów: Spostrzegam siebie jako osobę. Badany ustosunkowuje się do każdego samoopisu na 7-stopniowej skali Likerta (od $1-Z$ decydowanie się nie zgadzam do 7 - Zdecydowanie się zgadzam) (Sorokowska i in., 2014). Skale TIPI-PL mają stosunkowo niski wskaźnik alfa Cronbacha (tabela 1; dyskusja problemu analogicznej skali TIPI-P zob. Łaguna, Bąk, Purc, Mielniczuk, Oleś, 2014). Z dalszych analiz wykluczono wymiar otwartość na doświadczenie ze względu na jego bardzo niską rzetelność.

\section{Przekonania na temat świata}

Skala założeń wobec świata (World Assumptions Scale - WAS) jest samoopisowym kwestionariuszem składającym się z 32 itemów (Janoff-Bulman, 1989; polska adaptacja Załuski, Gajdosz, 2012). WAS składa się z trzech głównych kategorii założeń, na które z kolei składają się pomniejsze przekonania. Do kategorii pierwszej należą przekonania o dobroci otaczającego świata (życzliwość świata, benevolence of the world), na które składają się przekonania na temat tego, że świat jest dobry, a ludzie opiekuńczy i pomocni. W ramach kategorii drugiej znajdują się przekonania o sensowności i sprawiedliwości zdarzeń zachodzących w życiu i ich wytłumaczalności (sensowność świata, meaningfulness of the world). Kategoria trzecia zawiera natomiast przekonania na temat wartości własnej osoby (wartościowość ja, self-worth). Tworzą ją schematy na temat człowieka jako istoty $z$ natury dobrej i moralnej (1), efektywnej (2) i szczęśliwej (3). Badany wypełnia kwestionariusz, określając na 6-stopniowej skali Likerta, w jakim stopniu zgadza się z poszczególnymi stwierdzeniami. Wynik ostateczny jest przedstawiony w postaci sumy punktów w obrębie poszczególnych trzech grup przekonań. Im wyższy wynik, tym silniejsze przekonanie. Rzetelność narzędzia mierzona alfa Cronbacha jest zadowalająca (tabela 1).

\section{WYNIKI}

\section{Analiza danych}

Braki danych wynosiły 1,7\% wszystkich odpowiedzi udzielonych przez badanych. Analiza testem MCAR wykazała, że braki danych były całkowicie 
losowe, $\chi^{2}(233)=248.255, p=.235$, w związku z czym uzupełniono je za pomocą algorytmu EM (expectation-maximization) (Enders, 2001). Statystyki opisowe oraz korelacje między zmiennymi obliczono w programie IBM SPSS ver. 21. W analizie różnic międzypłciowych ze względu na dysproporcję w liczebności badanych kobiet i mężczyzn posłużono się rekomendowanym w ta- kich sytuacjach wskaźnikiem $g$ Hedgesa, który charakteryzuje się wrażliwością na wielkość grupy. Analizę mediacji moderowanej przeprowadzono za pomocą makra PROCESS, które umożliwia łączenie mediacji i moderacji w zintegrowanym modelu zwanym conditional process model (Hayes, 2013, s. 325). Koncepcyjny model testowanych zależności przedstawiono na rysunku 1 .

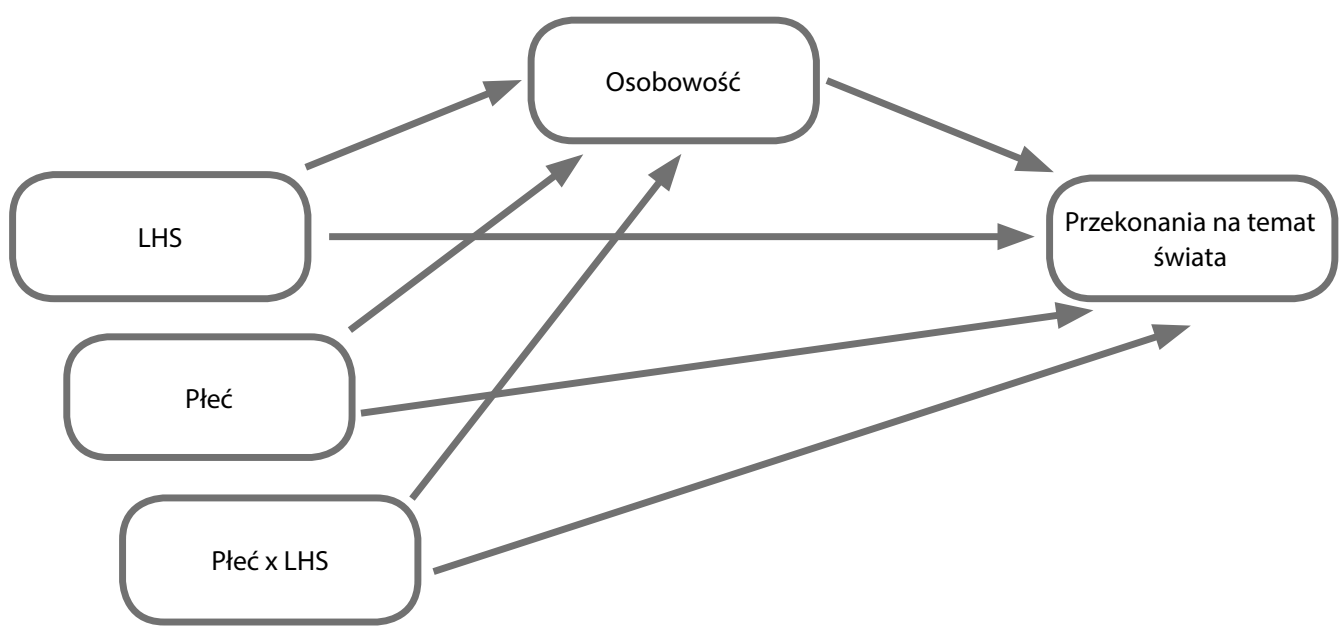

LHS - strategie reprodukcyjne związane z historią życia.

Rysunek 1. Model testowanej mediacji moderowanej

\section{Statystyki opisowe, korelacje i różnice międzypłciowe}

Średnie, odchylenia standardowe oraz korelacje między zmiennymi przedstawiono w tabeli 1. Przeprowadzona analiza różnic międzypłciowych w zakresie badanych zmiennych (tabela 2) wykazała, że kobiety charakteryzują się wyższym od mężczyzn wskaźnikiem wolnej strategii reprodukcyjnej $(g=.38)$, przy czym wielkość miary efektu $g$ Hedgesa wskazywała na małą różnicę. W przypadku cech osobowości kobiety ujawniły wyższy od mężczyzn poziom ekstrawersji $(g=.82)$, ugodowości $(g=$ $.86)$, sumienności ( $g=.65)$, a wielkość efektu $g$ Hedgesa wskazywała na duże różnice międzypłciowe w ekstrawersji i ugodowości oraz umiarkowaną różnicę w sumienności. Kobiety i mężczyźni nie różnili się od siebie pod wzglę- dem stabilności emocjonalnej. Ponadto kobiety w porównaniu z mężczyznami żywiły większe przekonanie co do wartościowości swojego ja ( $g=.69$ ) oraz życzliwości otaczającego świata $(g=.55)$. Obie wykazane różnice w obszarze założeń wobec świata kształtowały się na poziomie umiarkowanym. W przypadku przekonania o sensowności świata nie stwierdzono różnic międzypłciowych.

\section{Analiza moderowanej mediacji}

Przedstawione powyżej różnice w wynikach uzyskanych przez kobiety i mężczyzn uzasadniały konieczność uwzględnienia $\mathrm{w}$ analizach moderującej roli płci. $Z$ tego względu zarówno związki bezpośrednie pomiędzy strategiami reprodukcyjnymi związanymi z historią życia a przekonaniami na temat świata, jak i związki 
pośrednie pomiędzy tymi zmiennymi (tj. zachodzące za pośrednictwem cech osobowości) testowano w ramach modelu moderowanej mediacji za pomocą makra PROCESS autorstwa Andrew Hayesa (model 8; Hayes, 2013). Wykonano trzy odrębne analizy dla wartościowości ja, sensowności świata oraz życzliwości świata jako zmiennych zależnych. Każdorazowo jako zmienną niezależną wprowadzano strategie reprodukcyjne związane $\mathrm{z}$ historią życia jako równoczesne mediatory - cechy osobowości (ekstrawersja, ugodowość, sumienność, stabilność emocjonalna), a jako moderator - płeć badanych (kodowaną: 0 = kobieta, $1=$ mężczyzna). Zgodnie z rekomendacją Hayesa (2013) zmienne stanowiące składowe efektu interakcyjnego scentrowano. Istotność efektów określano za pomocą metody bootstrappingu z wykorzystaniem 10000 próbek oraz korektami dla 95\% przedziału ufności (CI).

Tabela 1. Statystyki opisowe oraz korelacje między zmiennymi

\begin{tabular}{|l|c|c|c|c|c|c|c|c|c|c|c|c|}
\hline & $\boldsymbol{M}$ & $\boldsymbol{S D}$ & $\boldsymbol{\alpha}$ & $\mathbf{1}$ & $\mathbf{2}$ & $\mathbf{3}$ & $\mathbf{4}$ & $\mathbf{5}$ & $\mathbf{6}$ & $\mathbf{7}$ & $\mathbf{8}$ & $\mathbf{9}$ \\
\hline Wiek & 27.25 & 7.53 & & - & & & & & & & & \\
\hline LHS & 1.36 & .38 & .93 & .02 & - & & & & & & & \\
\hline Ekstrawersja & 5.42 & 1.34 & .52 & $-.12 \dagger$ & $.28^{* * *}$ & - & & & & & & \\
\hline Ugodowość & 5.10 & 1.25 & .26 & -.05 & $.24^{* * *}$ & $.26^{* * *}$ & - & & & & & \\
\hline Sumienność & 5.26 & 1.46 & .69 & -.06 & $.25^{* * *}$ & $.38^{* * *}$ & $.40^{* * *}$ & - & & & & \\
\hline Stabilność & 4.09 & 1.49 & .57 & .10 & $.22^{* *}$ & $.31^{* * *}$ & $.21^{* *}$ & .10 & - & & & \\
\hline $\begin{array}{l}\text { Wartościo- } \\
\text { wość Ja }\end{array}$ & 4.12 & .72 & .81 & -.05 & $.42^{* * *}$ & $.45^{* * *}$ & $.33^{* * *}$ & $.38^{* * *}$ & $.34 * * *$ & - & & \\
\hline $\begin{array}{l}\text { Sensowność } \\
\text { świata }\end{array}$ & 3.49 & .58 & .61 & .08 & $.29^{* * *}$ & $.20^{* *}$ & $.19^{* *}$ & $.21^{* *}$ & $.24 * * *$ & $.38^{* * *}$ & - & \\
\hline $\begin{array}{l}\text { Życzliwość } \\
\text { świata }\end{array}$ & 3.96 & .82 & .79 & -.02 & $.28^{* * *}$ & $.28^{* * *}$ & $.40^{* * *}$ & $.20^{* *}$ & $.14^{*}$ & $.49^{* * *}$ & $.23 * * *$ & - \\
\hline
\end{tabular}

LHS - strategia reprodukcyjna związana z historią życia; $\uparrow p<.10{ }^{*} p<.05 ;{ }^{* *} p<.01 ; * * * p .001$

Tabela 2. Różnice międzypłciowe w zakresie badanych zmiennych

\begin{tabular}{|l|c|c|c|c|c|c|}
\hline \multirow{2}{*}{} & \multicolumn{2}{|c|}{ Kobiety (N= 183) } & \multicolumn{2}{c|}{ Mężczyźni (N= 61) } & \multirow{2}{*}{$\boldsymbol{t}$} & \multirow{2}{*}{} \\
\cline { 2 - 6 } & $\boldsymbol{M}$ & $\boldsymbol{S D}$ & $\boldsymbol{M}$ & $\boldsymbol{S D}$ & & \\
\hline LHS & 1.40 & .39 & 1.25 & .36 & 2.58 & .38 \\
\hline Ekstrawersja & 5.68 & 1.21 & 4.64 & 1.42 & 5.55 & .82 \\
\hline Ugodowość & 5.35 & 1.15 & 4.34 & 1.22 & 5.87 & .86 \\
\hline Sumienność & 5.48 & 1.37 & 4.57 & 1.51 & 4.38 & .65 \\
\hline Stabilność & 4.03 & 1.50 & 4.24 & 1.45 & -.98 & -.14 \\
\hline Wartościowość Ja & 4.24 & .70 & 3.76 & .64 & 4.71 & .69 \\
\hline Sensowność świata & 3.48 & .59 & 3.50 & .57 & -.23 & -.03 \\
\hline Życzliwość świata & 4.07 & .79 & 3.63 & .83 & 3.76 & .55 \\
\hline
\end{tabular}

LHS - strategia reprodukcyjna związana z historią życia

\section{Analiza efektów bezpośrednich}

Analiza efektów bezpośrednich (tabela 3) wykazała powiązanie wolnej strategii reprodukcyjnej z każdą z uwzględnionych w badaniu cech osobowości - ekstrawersją $(\beta=.33, p<.001)$, ugodowością $(\beta=.31, p<.001)$, sumiennością $(\beta=.37=, p<.01)$ oraz stabilnością emocjonalną $(\beta=.42, p<.001)$. Analogicznie wolna 
strategia reprodukcyjna korespondowała z poszczególnymi przekonaniami - wartościowością ja $(\beta=.44, p<.001)$, sensownością świata $(\beta=.31, p<.01)$ oraz życzliwością świata $(\beta=.28, p<.05)$. Ponadto wykazano związki pomiędzy cechami osobowości a przekonaniami. Z wartościowością ja wiązały się ekstrawersja $(\beta=.27, p<.01)$, sumienność $(\beta=.19$, $p<.001)$ oraz stabilność emocjonalna $(\beta=.21$, $p<.001)$. Z przekonaniem o sensowności świata korespondowały $\mathrm{z}$ kolei sumienność $(\beta=$ $.14, p<.05)$ i stabilność emocjonalna $(\beta=.14$, $p<.05)$. W przypadku przekonania o życzliwości otaczającego świata istotne okazały się natomiast związki z ekstrawersją $(\beta=.22, p<$ $.05)$ i ugodowością $(\beta=.33, p<.001)$. Efekt płci ujawnił się $\mathrm{w}$ testowanym modelu $\mathrm{w}$ przypadku ekstrawersji $(\beta=-.42, p<.001)$, ugodowości $(\beta=-.80, p<.001)$, sumienności $(\beta=-.48$, $p<.01)$ oraz założeniu o wartościowości ja $(\beta=-.35, p<.05)$. W przypadku każdej z tych zmiennych kobiety uzyskiwały istotnie wyższe wyniki niż mężczyźni. Ponadto płeć moderowała związki historii życia $\mathrm{z}$ ugodowością $(\beta=-.57, p<.01)$, sumiennością $(\beta=.59$, $p<.01)$ oraz wartościowością ja $(\beta=-.54$, $p<.01)$. Efekty te informują o tym, że podczas gdy w przypadku kobiet strategia reprodukcyjna związana $\mathrm{z}$ historią życia była istotnym predyktorem ugodowości oraz wartościowości ja, u mężczyzn efekt ten nie występował. Analogicznie strategia reprodukcyjna związana z historią życia okazała się istotnym predyktorem sumienności tylko w grupie mężczyzn.

Zaprezentowany model zależności wyjaśniał 39\% wariancji przekonania o wartościowości ja, 15\% wariancji przekonania o sensowności świata oraz $21 \%$ wariancji przekonania o życzliwości świata.

\section{Analiza efektów pośrednich}

W dalszej części analizy obliczono warunkowe efekty pośrednie (conditional indirect effects; Hayes, 2013), które pozwoliły określić mediacyjny udział cech osobowości kobiet i mężczyzn w relacji pomiędzy historią życia a przekonaniami na temat świata. W związku wolnej strategii reprodukcyjnej z przekonaniem o wartościowości ja u kobiet istotnymi mediatorami oka-
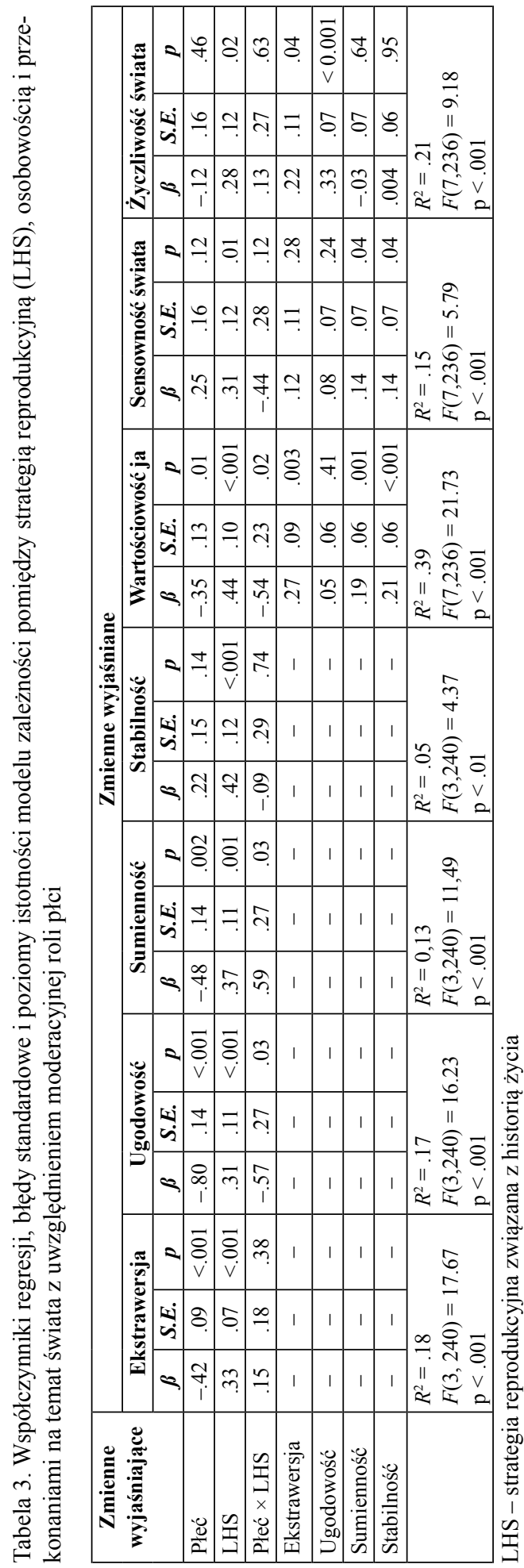
zały się ekstrawersja $(b=.08, S E=.04,95 \%$ $\mathrm{CI}=<.019 ; .186>)$ i stabilność emocjonalna $(b=.09, S E=.04,95 \% \mathrm{CI}=<.025 ; .192>)$, a u mężczyzn - ekstrawersja $(b=.12, S E=.08$, $95 \% \mathrm{CI}=<.003 ; .343>)$ i sumienność $(b=.16$, $S E=.07,95 \% \mathrm{CI}=<.052 ; .324>)$. Ponieważ, jak wykazano wcześniej, bezpośredni związek strategii reprodukcyjnej z wartościowością ja okazał się istotny tylko u kobiet, w przypadku tej grupy była to mediacja częściowa, u mężczyzn zaś - mediacja całkowita. W związku wolnej strategii reprodukcyjnej z przekonaniem o sensowności świata wykazano dwie częściowe mediacje, u mężczyzn - stabilności emocjonalnej $(b=.06, S E=.04,95 \% \mathrm{CI}=<.007 ; .163>)$, a u kobiet-sumienności $(b=.12, S E=.07,95 \%$ $\mathrm{CI}=<.001 ; .298>$ ). W przypadku przekonania o życzliwości świata efekty pośrednie wystąpiły tylko w grupie kobiet. Efekty te informują o tym, że związek wolnej strategii reprodukcyjnej z tym przekonaniem można u kobiet częściowo wyjaśnić poziomem ekstrawersji $(b=.06, S E=.04$, $95 \% \mathrm{CI}=<.006 ; .167>)$ i ugodowości $(b=.15$, $S E=.05,95 \% \mathrm{CI}=<.061 ; .273>$ ).

Tabela 4. Efekty mediacyjne cech osobowości w relacji pomiędzy strategią reprodukcyjną (LHS) a przekonaniami na temat świata z uwzględnieniem moderacyjnej roli płci

\begin{tabular}{|c|c|c|c|c|c|}
\hline Zmienna zależna & Mediator & Pleć & $b$ & $S E$ & $95 \% C I$ \\
\hline \multirow[t]{8}{*}{ Wartościowość ja } & \multirow[t]{2}{*}{ Ekstrawersja } & Kobiety & .08 & .04 & {$[.019 ; .186]$} \\
\hline & & Mężczyźni & .12 & .08 & {$[.003 ; .343]$} \\
\hline & \multirow[t]{2}{*}{ Ugodowość } & Kobiety & .02 & .03 & {$[-.025 ; .098]$} \\
\hline & & Mężczyźni & -.01 & .02 & {$[-.082 ; .023]$} \\
\hline & \multirow[t]{2}{*}{ Sumienność } & Kobiety & .04 & .03 & {$[-.002 ; .125]$} \\
\hline & & Mężczyźni & .16 & .07 & {$[.052 ; .324]$} \\
\hline & \multirow[t]{2}{*}{ Stabilność } & Kobiety & .09 & .04 & {$[.025 ; .192]$} \\
\hline & & Mężczyźni & .07 & .06 & {$[-.026 ; .203]$} \\
\hline \multirow[t]{8}{*}{ Sensowność świata } & \multirow[t]{2}{*}{ Ekstrawersja } & Kobiety & .03 & .04 & {$[-.027 ; .147]$} \\
\hline & & Mężczyźni & .05 & .07 & {$[-.035 ; .266]$} \\
\hline & \multirow[t]{2}{*}{ Ugodowość } & \begin{tabular}{|l|} 
Kobiety \\
\end{tabular} & .04 & .04 & {$[-.020 ; .131]$} \\
\hline & & Mężczyźni & -.01 & .04 & {$[-.125 ; .036]$} \\
\hline & \multirow[t]{2}{*}{ Sumienność } & Kobiety & .03 & .03 & {$[-.003 ; .121]$} \\
\hline & & Mężczyźni & .12 & .07 & {$[.001 ; .298]$} \\
\hline & \multirow[t]{2}{*}{ Stabilność } & Kobiety & .06 & .04 & {$[.007 ; .163]$} \\
\hline & & Mężczyźni & .05 & .04 & {$[-.010 ; .170]$} \\
\hline \multirow[t]{8}{*}{ Życzliwość świata } & \multirow[t]{2}{*}{ Ekstrawersja } & Kobiety & .06 & .04 & {$[.006 ; .167]$} \\
\hline & & Mężczyźni & .10 & .08 & {$[-.005 ; .299]$} \\
\hline & \multirow[t]{2}{*}{ Ugodowość } & Kobiety & .15 & .05 & {$[.061 ; .273]$} \\
\hline & & Mężczyźni & -.04 & .10 & {$[-.252 ; .150]$} \\
\hline & \multirow[t]{2}{*}{ Sumienność } & Kobiety & -.007 & .02 & {$[-.062 ; .017]$} \\
\hline & & Mężczyźni & -.03 & .05 & {$[-.142 ; .075]$} \\
\hline & \multirow[t]{2}{*}{ Stabilność } & Kobiety & .002 & .03 & {$[-.063 ; .066]$} \\
\hline & & Mężczyźni & .002 & .03 & {$[-.048 ; .067]$} \\
\hline
\end{tabular}

$b$ - niestandaryzowany współczynnik ścieżki pośredniej; $S E$ - błąd standardowy; 95\% CI - przedział ufności dla współczynnika ścieżki pośredniej, uzyskany w procedurze bootstrappingu (10 000 próbek) 


\section{DYSKUSJA WYNIKÓW}

W prezentowanych badaniach testowaliśmy model związków pomiędzy strategią reprodukcyjną a światopoglądem z uwzględnieniem mediacyjnej roli cech osobowości. Zgodnie z założeniami wykazaliśmy, że wymiary stabilności emocjonalnej, sumienności, ekstrawersji, ugodowości stanowią istotne mediatory relacji pomiędzy strategiami reprodukcyjnymi związanymi z historią życia a różnymi aspektami światopoglądu. Dodatkowo uwzględniono zmienną ,płeć" i analiza moderowanej mediacji wykazała istotną rolę tej zmiennej w testowanym modelu. Oznacza to, że mediacyjna rola osobowości między strategiami reprodukcyjnymi a światopoglądem uzależniona jest także od płci.

W przedstawionych badaniach potwierdziliśmy hipotezę, że wolna strategia reprodukcyjna wiąże się z wyższym poziomem wartościowości ja, życzliwości wobec świata oraz sensowności świata. Tak ukształtowany schemat siebie i świata może mieć pozytywne konsekwencje psychologiczne i zdrowotne. Prawdopodobnie pośredniczy w bardziej prospołecznych zachowaniach opartych nie na antagonizmie, lecz współpracy, co jest cechą charakterystyczną wolnej strategii reprodukcyjnej (Figueredo, Jacobs, 2010). Pozytywny światopogląd może także umożliwiać lepsze radzenie sobie ze stresem i depresją (Neblett, Hammond, Seaton, Townsend, 2010). Należy dodać, że faktycznie osoby o wolnej strategii mają także wyższy wskaźnik ogólnej witalności (covitality factor) zawierający ocenę dobrostanu fizycznego i psychicznego (Figueredo i in., 2004), co wskazuje na rozwój zdeterminowany wysiłkiem somatycznym.

Uzyskane rezultaty replikują wyniki uzyskane w innych badaniach dotyczących dodatnich zależności między wolną strategią reprodukcyjną a takimi cechami osobowości, jak sumienność, ugodowość, stabilność emocjonalna (Banai, Pavela, 2015; Holtzman, Strube, 2013), ekstrawersja (Gladden i in., 2009, Manson, 2015).

W przypadku wartościowości ja, oprócz wolnej strategii reprodukcyjnej, predyktorami okazały się stabilność emocjonalna, ekstrawersja i sumienność. Wyniki te pozostają w zgodzie z wcześniejszymi doniesieniami z badań nad samooceną. Wykazano w nich, że właśnie te cechy spośród wielkiej piątki stanowią kluczowe predyktory oceny wartościowości własnej osoby, a istotność pozostałych cech, to jest ugodowości i otwartości, zanika całkowicie przy uwzględnieniu wpływu zmiennej aprobaty społecznej (Robins i in., 2001).

Stabilność emocjonalna obok sumienności okazała się również predyktorem przekonania o sensowności świata. Biorąc pod uwagę, że Ronnie Janoff-Bulman i Cynthia McPherson Frantz (1997) podkreślają, iż sensowność świata zawiera się w przekonaniu, że istnieje związek między tym, co zrobi jednostka, a wynikami działania, oraz poczuciu kontroli nad zdarzeniami, wynik ten jest spójny $\mathrm{z}$ doniesieniami z badań, które pokazują, że osoby, które mają wewnętrzne poczucie kontroli, są emocjonalnie zrównoważone (Jain, Singh, 2015). Poziom sumienności również pozwala przewidywać stopień przekonania o sensowności świata. Ma to potwierdzenie w innych badaniach, w których wykazano, że sumienność koreluje dodatnio $\mathrm{z}$ ogólnym poczuciem koherencji (sense of coherence), jak również z jego trzema wymiarami: poczuciem zrozumiałości, zaradności oraz sensowności (Kase, Ueno, Oishi, 2018). Poczucie koherencji odzwierciedla - w szczególności w zakresie wymiaru zrozumiałości sposób spostrzegania świata wewnętrznego i zewnętrznego jako racjonalnie zrozumiałego, uporządkowanego i ustrukturalizowanego (Eriksson, Mittelmark, 2017). Skłonność do porządku, planowania, samodyscyplina moga być także związane $\mathrm{z}$ określonymi wartościami człowieka, które stanowią filtr, przez który postrzegany jest świat. Wykazano na przykład, że sumienność koreluje z konformizmem i potrzebą bezpieczeństwa $\mathrm{z}$ teorii wartości Shaloma Schwartza (1992), a więc konserwatywnymi wartościami, których istotą są porządek społeczny, unikanie jego naruszania, wierność zasadom i uchylanie się od ryzyka (Parks-Leduc, Feldman, Bardi, 2015; Roccas, Sagiv, Schwartz, Knafo, 2002). Prawdopodobnie taki sposób postrzegania świata sprzyja interpretowaniu 
go w kategoriach sensu i kontroli. Potwierdzają to badania, w których wykazano, że o ile osoby ekstrawertywne i otwarte na doświadczenie mogą czerpać sens z kwestionowania ustalonego porządku, o tyle osoby charakteryzujące się wysokim poziomem sumienności czerpią poczucie sensu z tradycyjnych, dobrze ugruntowanych i społecznie podzielanych obszarów funkcjonowania związanych z sukcesami na polu zawodowym, zaangażowaniem w życie rodzinne oraz dobrym stanem zdrowia (Lavigne, Hofman, Ring, Ryder, Woodward, 2013).

Ekstrawersja wraz z ugodowością stanowią z kolei, obok wolnej strategii reprodukcyjnej, kluczowe predyktory przekonania o życzliwości świata, co potwierdza wyniki wcześniejszych badań (Poulin, Silver, 2008). Dodatkowe analizy pozwalają stwierdzić, że ekstrawersja jest w tym wypadku mediatorem związków strategii reprodukcyjnej ze wspomnianym przekonaniem. Sugeruje to, że rodzicielskie ciepło wpływa na poziom ekstrawersji w dzieciństwie (Persson, 2014), a ta z kolei umożliwia postrzeganie świata i innych ludzi w kategoriach dobroczynności i życzliwości. Dane te są spójne z wynikami wskazującymi, że osoby ekstrawertywne łatwiej dostrzegają pozytywne aspekty zdarzeń życiowych (Uziel, 2006). Taka percepcja świata umożliwia wykorzystanie psychologicznego potencjału osobowości związanego z kompetencjami społecznymi i lepsze radzenie sobie $\mathrm{z}$ negatywnymi sytuacjami życiowymi. Dotychczasowe badania sugerują, że osoby ekstrawertywne stosują skoncentrowane na problemie sposoby radzenia sobie ze stresem (zob. Jackson, Schneider, 2014) oraz mają większe szanse na wzrost potraumatyczny (Jia, Ying, Zhou, Wu, Lin, 2015). Osoby ekstrawertywne mają również więcej społecznych kompetencji niż osoby introwertywne, co pomaga im w zdobyciu wyższego statusu społecznego i szacunku ze strony innych osób (Anderson, John, Keltner, Kring, 2001), a to z kolei może prowadzić do postrzegania otoczenia społecznego jako sprzyjającego jednostce.

W naszych analizach płeć okazała się istotnym moderatorem związków pośrednich pomię- dzy strategią reprodukcyjną a przekonaniami. U mężczyzn postrzeganie świata w kategoriach życzliwości wynika z wysokich nakładów rodzicielskich charakterystycznych dla wolnej strategii reprodukcyjnej, natomiast u kobiet dodatkowo zapośredniczone jest poziomem ekstrawersji i ugodowości, a więc cech, które są związane $\mathrm{z}$ otwartością interpersonalną i nastawieniem prospołecznym. Cechy te, jak wykazano we wcześniejszych badaniach, są predyktorem pozytywnej wizji natury ludzkiej (Chen i in., 2006).

Zarówno u kobiet, jak i u mężczyzn istotnym mediatorem związków strategii reprodukcyjnej z wartościowością ja okazała się ekstrawersja. Już wcześniejsze badania wykazały, że wolna strategii reprodukcyjna jest predyktorem ekstrawersji (por. Chen, Shi, Sun, 2017), która z kolei jest istotnym czynnikiem wzmacniającym poczucie własnej wartości i samoocenę (Robins $\mathrm{i}$ in., 2001; Erdle i in., 2009; Sharpe i in., 2011). U mężczyzn cechą mediującą związek pomiędzy strategią reprodukcyjną a wartościowością ja jest, oprócz ekstrawersji, sumienność. Obie cechy składają się na tak zwany wymiar sprawczości w obrębie wielkiej piątki, a właściwości odnoszące się do sprawczości są lepszym predyktorem samooceny u mężczyzn niż u kobiet (Block, Robins, 1993; Robins i in., 2001). $\mathrm{U}$ kobiet natomiast $\mathrm{w}$ relacji pomiędzy strategią reprodukcyjną a przekonaniami wyrażającymi poczucie własnej wartości pośredniczy, obok ekstrawersji, stabilność emocjonalna, a więc cecha osobowości, która u kobiet ogólnie występuje na niższym poziomie $\mathrm{w}$ porównaniu z mężczyznami (por. Wojciszke, 2010). Równocześnie stabilność emocjonalna jest cechą istotnie związaną z wolną strategią reprodukcyjną (np. Banai, Pavela, 2015; van Leeuven, Mace, 2016). Otrzymany rezultat sugeruje, że $\mathrm{u}$ badanych kobiet strategia wolna powiązana jest jednak ze stabilnością emocjonalną. Ta z kolei może wpływać na przekonania o własnej wartościowości dwojako. Po pierwsze, ogólnie osoby stabilne emocjonalnie mają wyższą samoocenę, ponieważ stabilność emocjonalna jest cechą pożądaną społecznie (Robins i in., 2001). Po drugie, stabilność emocjonalna jest ważną cechą braną pod uwagę przy wyborze partnera 
w związku nie tylko przez kobiety, ale i mężczyzn (Botwin, Buss, Shackelford, 1997). Zatem jej posiadanie przez kobiety o wolnej strategii może być istotne zarówno dla powodzenia strategii reprodukcyjnej, jak i wartościowości ja.

Uzyskane wyniki wskazują również na odrębne mediatory dla kobiet i mężczyzn w przypadku związku strategii reprodukcyjnej z przekonaniem o sensowności świata. U mężczyzn istotnym mediatorem tej zależności jest stabilność emocjonalna, a zatem cecha, która - jak wspomniano - jest bardziej domeną mężczyzn niż kobiet. W przypadku kobiet takim mediatorem jest sumienność, która z kolei charakteryzuje nieco bardziej kobiety niż mężczyzn (Schmitt, Realo, Voracek, Alik, 2008). Mediatory związków strategii reprodukcyjnej z postrzeganą sensownością świata stanowią zatem cechy osobowości charakterystyczne dla obu płci, a ich rozwój dostarcza odmiennych dla kobiet i mężczyzn wskazówek na temat zrozumiałości i przewidywalności otaczającego świata.

\section{KONKLUZJA}

Ewolucyjna psychologia rozwojowa wpisuje się w szerszy kontekst badań psychologii rozwojowej związany z odpowiedzią na pytanie, czy i w jaki sposób różnego rodzaju doświadczenia wczesnodziecięce determinują późniejszy rozwój człowieka. W prezentowanych badaniach testowaliśmy za pomocą analizy równań strukturalnych model, zgodnie z którym cechy osobowości są mediatorem między kształtowanymi w dzieciństwie strategiami reprodukcyjnymi a światopoglądem. Stabilność emocjonalna, sumienność, ugodowość i ekstrawersja okazały się mediatorami między strategiami reprodukcyjnymi a światopoglądem, jednocześnie moderatorem zależności była płeć badanych. Zgodnie z założeniami teorii historii życia wskazuje to na rolę wczesnodziecięcych doświadczeń w kształtowaniu światopoglądu. W świetle założeń teorii historii życia można postawić hipotezę, zgodnie z którą źródło różnic między kobietami a mężczyznami znajduje się w doświadczeniach wczesnodziecięcych. Na przykład ugodowość, sumienność, stabilność emocjonalna mają związek z bezpiecznym stylem przywiązania w dzieciństwie i z wolną strategią reprodukcyjną (Young i in., 2017). Ekstrawersja związana jest z bezpiecznym stylem przywiązania (Fransson, Granqvist, Bohlin, Hagekull, 2013) i z wolną strategią reprodukcyjną (Gladden i in., 2009). Wydaje się więc, że u obu płci z wolną strategią reprodukcyjną, poprzez relacje $\mathrm{z}$ opiekunem $\mathrm{w}$ dzieciństwie, tworzone są ramy dla rozwoju w późniejszym okresie cech osobowości wpływających na poszczególne aspekty światopoglądu. Rozwijając hipotezę, można zasugerować, że styl przywiązania $\mathrm{w}$ dzieciństwie dostarcza także zależnych od płci dziecka wskazówek dotyczących ważności różnych aspektów światopoglądu (np. wartościowości ja) i służących do wiązania w przyszłości cech osobowości ze światopoglądem. Kwestia ta wymaga jednak dalszych badań, w szczególności w odniesieniu do zróżnicowania tych doświadczeń ze względu na płeć i ich wpływu na kształtowanie strategii reprodukcyjnych.

W kolejnych próbach uchwycenia omawianej problematyki warto uniknąć kilku ograniczeń związanych z prezentowanymi badaniami. Po pierwsze, ze względu na problemy z niską rzetelnością podskal Inwentarza TIPI-PL należy rozważyć zastosowanie dłuższych narzędzi do pomiaru wielkiej piątki, na przykład NEO-FFI (NEO Five Factor Inventory; McCrae, Costa, 2004).

$\mathrm{W}$ prezentowanych badaniach zdecydowaną większość respondentów stanowiły kobiety, przez co analizy różnic międzypłciowych należy interpretować z ostrożnością, gdyż wymagają one potwierdzenia $\mathrm{w}$ próbach lepiej zrównoważonych pod względem płci badanych.

Wreszcie ze względu na zastosowanie metodologii korelacyjno-regresyjnej, która nie uprawnia do rozstrzygania o relacjach przyczynowo-skutkowych pomiędzy zmiennymi, postulowane zależności, choć mają oparcie w uznanych teoriach psychologicznych oraz danych empirycznych, wymagają replikacji w badaniach o charakterze podłużnym. 


\section{BIBLIOGRAFIA}

Alvergne A., Jokela M., Lummaa V. (2010). Personality and reproductive success in a high-fertility human population. Proceedings of the National Academy of Sciences of the United States of America, 107, 11745-11750.

Anderson C., John O.P., Keltner D., Kring A.M. (2001). Who attains social status? Effects of personality and physical attractiveness in social groups. Journal of Personality and. Social Psychology, 81, 116-132.

Banai B., Pavela I. (2015). Two-dimensional structure of the Sociosexual Orientation Inventory and its personality correlates. Evolutionary Psychology, 13, 1-7.

Barbaro N., Boutwell B.B., Barnes J.C., Shackelford, T.K. (2017). Genetic confounding of the relationship between father absence and age at menarche. Evolution and Human Behavior, 38, 357-365. http://dx.doi. org/10.1016/j.evolhumbehav.2016.11.007.

Beaver K.M, Hartman S., Belsky J. (2015). Differential susceptibility to parental sensitivity based on earlylife temperament in the prediction of adolescent affective psychopathic personality traits. Criminal Justice and Behavior, 42(5), 546-565. http://dx.doi.org/10.1177/0093854814553620.

Belsky J., Steinberg L., Draper P. (1991). Childhood experience, interpersonal development, and reproductive strategy: and evolutionary theory of socialization. Child Development, 62, 647-670.

Block J., Robins R.W. (1993). A longitudinal study of consistency and change in self esteem from early adolescence to early adulthood. Child Development, 64, 909-923.

Botwin M.D., Buss D.M., Shackelford T.K. (1997). Personality and mate preferences: five factors in mate selection and marital satisfaction. Journal of Personality, 65, 107-136.

Buss D.M. (1991). Evolutionary personality psychology. Annual Review of Psychology, 42, 459-491.

Buss D.M. (2009). How Can evolutionary psychology successfully explain personality and individual differences? Perspectives on Psychological Science, 4, 359-366.

Chang L., Lu H.J. (2018). Resource and extrinsic risk in defining fast life histories of rural Chinese left-behind children. Evolution of Human Behavior, 39, 59-66.

Chen S.X., Fok H.K., Bond M.H., Matsumoto D. (2006). Personality and beliefs about the world revisited: Expanding the nomological network of social axioms. Personality and Individual Differences, 41, 201-211.

Chen B.-B., Shi Z., Sun S. (2017). Life history strategy as a mediator between childhood environmental unpredictability and adulthood personality. Personality and Individual Differences, 111, 215-219. https:// doi.org/10.1016/j.paid.2017.02.032.

Cieciuch J. (2005). Czym jest światopogląd? Filozoficzny kontekst psychologicznego pojęcia. Psychologia Rozwojowa, 10, 147-159.

Copping L.T., Campbell A., Muncer S. (2014). Psychometrics and life history strategy: The structure and validity of the high K strategy scale. Evolutionary Psychology, 12, 200-222.

Costa P.T., McCrae R.R. (1992). Professional manual: Revised NEO personality inventory (NEO-PI-R) and NEO five-factor inventory (NEO-FFI). Odessa FL: Psychological Assessment Resources.

Csathó Á., Birkás B. (2018). Early-life stressors, personality development, and fast life strategies: An evolutionary perspective on malevolent personality features. Frontiers in Psychology, 9, 305.

Del Giudice M., Belsky J. (2011). The development of life history strategies: Toward a multi-stage theory. W: D.M. Buss, P.H. Hawley (eds.), The Evolution of Personality and Individual Differences, 154-176. New York: Oxford University Press.

Draper P., Harpending H. (1982). Father absence and reproductive strategy: An evolutionary perspective. Journal of Anthropological Research, 38, 255-273.

Ellis B.J. (2004). Timing of pubertal maturation in girls: An integrated life history approach. Psychological Bulletin, 130, 920-958.

Enders C.K. (2001). The impact of nonnormality on full information maximum-likelihood estimation for structural equation models with missing data. Psychological Methods, 6(4), 352-370. http://dx.doi. org/10.1037/1082-989X.6.4.352.

Erdle S., Gosling S.D., Potter J. (2009). Does self-esteem account for the higher-order factors of the Big Five? Journal of Research in Personality, 43, 921-922. 
Eriksson M., Mittelmark M.B. (2017). The sense of coherence and its measurement. W: M.B. Mittelmark, S. Sagy, M. Eriksson, G.F. Bauer, J.M. Pelikan, B. Lindström, G.A. Espnes (eds.), The Handbook of Salutogenesis, 97-106. Cham: Springer International Publishing. https://doi.org/10.1007/978-3-319-04600-6_12.

Figueredo A.J., Andrzejczak D.J., Jones D.N., Smith-Castro V., Montero E. (2011). Reproductive strategy and ethnic conflict: Slow life history as a protective factor against negative ethnocentrism in two contemporary societies. Journal of Social, Evolutionary, and Cultural Psychology, 5, 14-31.

Figueredo A.J., Cabeza de Baca T., Woodley M.A. (2013). The measurement of human life history strategy. Personality and Individual Differences, 55, 251-255.

Figueredo A.J., Cuthbertson A.M., Kauffman I.A., Weil E., Gladden P.R. (2012). The interplay of behavioral dispositions and cognitive abilities: Sociosexual orientation, emotional intelligence, executive functions and life history strategy. Temas em Psicologia, 20, 87-100.

Figueredo A.J., Gladden P.R., Beck C.J.A. (2010). Intimate partner violence and life history strategy. W: A. Goetz, T. Shackelford (eds.), The Oxford Handbook of Sexual Conflict in Humans, 72-99. New York, NY: Oxford University Press.

Figueredo A.J., Jacobs W.J. (2010). Aggression, risk-taking, and alternative life history strategies: The behavioral ecology of social deviance. W: M. Frias-Armenta, V. Corral-Verdugo (eds.), Bio-psycho-social perspectives on interpersonal violence, 3-28. Hauppauge, NY: Nova Science Publishers.

Figueredo A.J., Jacobs W.J., Gladden P.R., Bianchi J., Patch E.A., Kavanagh P.S., Li N.P. (2018). Intimate partner violence, interpersonal aggression, and life history strategy. Evolutionary Behavioral Sciences, 12, 1-31.

Figueredo A.J., Vásquez G., Brumbach B.H., Schneider S.M.R. (2004). The heritability of life history strategy: The K-factor, covitality, and personality. Social Biology, 51, 121-143.

Figueredo A.J., Vásquez G., Brumbach B.H., Schneider S.M.R., Sefcek J.A., Tal I.R., Jacobs W.J. (2006). Consilience and life history theory: From genes to brain to reproductive strategy. Developmental Psychology, 26, 243-275.

Fransson M., Granqvist P., Bohlin G., Hagekull B. (2013). Interlinkages between attachment and the Five-Factor Model of personality in middle childhood and young adulthood: A longitudinal approach. Attachment \& Human Development, 15, 219-213.

Fraley R.C., Roisman G.I., Haltigan J.D. (2013). The legacy of early experiences in development: Formalizing alternative models of how early experiences are carried forward over time. Developmental Psychology, 49, 109-126. doi:10.1037/a0027852.

Gadgil M., Bossert W.H. (1970). Life historical consequences of natural selection. American Naturalist, 104, 1-24.

Gladden P.R., Figueredo A.J., Jacobs W.J. (2009). Life history strategy, psychopathic attitudes, personality, and general intelligence. Personality and Individual Differences, 46, 270-275.

Gladden P.R., Figueredo A.J., Snyder B. (2010). Life history strategy and evaluative self-assessment. Personality and Individual Differences, 48, 731-735.

Gladden P.R., Figueredo A.J., Andrzejczak D.J., Jones D.N., Smith-Castro V. (2013). Reproductive strategy and sexual conflict slow life history strategy inhibits negative androcentrism. Journal of Methods and Measurement in the Social Sciences, 4, 48-71.

Gosling S.D., Rentfrow P.J., Swann W.B. Jr. (2003). A very brief measure of the Big-Five personality domains. Journal of Research in Personality, 37(6), 504-528. http://dx.doi.org/10.1016/S0092-6566(03)00046-1.

Grevenstein D., Bluemke M. (2015). Can the Big Five explain the criterion validity of sense of coherence for mental health, life satisfaction, and personal distress? Personality and Individual Differences, 77, $106-111$.

Griskevicius V., Ackerman J.M., Cantú S.M., Delton A.W., Robertson T.E., Simpson J., Tybur J.M. (2013). When the economy falters, do people spend or save? Responses to resource scarcity depend on childhood environments. Psychological Science, 24, 197-205.

Griskevicius V., Tybur J.M., Delton A.W., Robertson T.E. (2011). The influence of mortality and socioeconomic status on risk and delayed rewards: A Life History Theory approach. Journal of Personality and Social Psychology, 100, 1015-1026.

Hayes A.F. (2013). Introduction to Mediation, Moderation, and Conditional Process Analysis. New York: The Guilford Press. 
Hirsh J.B., DeYoung C.G., Xiaowen X., Peterson J.B. (2010). Compassionate liberals and polite conservatives: Associations of agreeableness with political ideology and moral values. Personality and Social Psychology Bulletin, 36(5), 655-664.

Hochberg Z. (2011). Evolutionary Perspective in child growth. Rambam Maimonides Medical Journal, 2, e0057. doi:10.5041/RMMJ.10057.

Holtzman N.S., Strube M.J. (2013). Above and beyond short-term mating, long-term mating is uniquely tied to human personality. Evolutionary Psychology, 11, 1101-1129.

Jackson S.M., Schneider T.R. (2014). Extraversion and stress W: A.D. Haddock, A.P. Rutkowski (eds.), Psychology of Extraversion, 121-131. Hauppauge, NY: Nova Science Publishers, Inc.

Jain M., Singh S. (2015). Locus of control and its relationship with mental health and adjustment among adolescent females. Journal of Mental Health and Human Behavior, 20, 16-21.

Janoff-Bulman R. (1989). Assumptive worlds and the stress of traumatic events: Applications of the schema construct. Social Cognition, 7, 113-136.

Janoff-Bulman R. (1992). Shattered Assumptions: Towards a New Psychology of Trauma. New York: The Free Press.

Janoff-Bulman R., McPherson Frantz C. (1997). The impact of trauma on meaning: From meaningless world to meaningful life. The Transformation of Meaning in Psychological Therapies: Integrating Theory and Practice, 91-106.

Jia X., Ying L., Zhou X., Wu X., Lin C. (2015). The Effects of extraversion, social support on the posttraumatic stress disorder and posttraumatic growth of adolescent survivors of the Wenchuan Earthquake. PLoS ONE. 10. e0121480.doi:10.1371/journal.pone.0121480.

John O.P., Srivastava S. (1999). The Big Five trait taxonomy: History, measurement, and theoretical perspectives. Handbook of Personality: Theory and Research, 2(510), 102-138.

Jokela M., Alvergne A., Pollet T.V., Lummaa V. (2011). Reproductive behavior and personality traits of the Five Factor Model. European Journal of Personality, 25, 487-500.

Jonason P.K. Webster G.W., Schmitt D.P., Li N.P., Crysel L. (2012). The antihero in popular culture: A life history theory of the Dark Triad. Review of General Psychology, 16, 192-199.

Jonason P.K., Cheng P., Li N., Czarna A. (2013). Quick and dirty: Some psychosocial costs associated with the Dark Triad in three countries. Evolutionary Psychology, 11, 172-185.

Judge T.A., Jackson C.L., Shaw J.C., Scott B.A., Rich B.L. (2007). Self-efficacy and work-related performance: The integral role if individual differences. Journal of Applied Psychology, 92, 107-127.

Kase T., Ueno Y., Oishi K. (2018). The overlap of sense of coherence and the Big Five personality traits: A confirmatory study. Health Psychology Open. https://doi.org/10.1177/2055102918810654.

Koltko-Rivera M.E. (2004). The psychology of worldviews. Review of General Psychology, 8, 3-58.

Lavigne K.M., Hofman S., Ring A.J., Ryder A.G., Woodward T.S. (2013). The personality of meaning in life: Associations between dimensions of life meaning and the Big Five. The Journal of Positive Psychology, 8(1), 34-43. https://doi.org/10.1080/17439760.2012.736527.

Łaguna M., Bąk W., Purc E., Mielniczuk E., Oleś P. (2014). Short measure of personality TIPI-P in a Polish sample. Roczniki Psychologiczne, 17, 421-437.

Łukasik A., Wołpiuk-Ochocińska A., Borawski D. (2018). Testing the indirect effects of somatic and parental effort on stress: The roles of worldviews and coping strategies. Current Psychology, 1-14. https:// doi.org/10.1007/s12144-018-0065-7.

Machluf K., Bjorklund D.F. (2015). Understanding risk-taking behavior: Insights from evolutionary psychology. W: R.A. Scott, S.M. Kosslyn, M. Buchmann (eds.), Emerging Trends in the Social and Behavioral Sciences. An Interdisciplinary, Searchable, and Linkable Resource, 1-15. Hoboken, N.J.: John Wiley \& Sons, Inc. doi:10.1002/9781118900772.etrds0375.

Machluf K., Liddle J.R., Bjorklund D.F. (2014). An introduction to evolutionary developmental psychology. Evolutionary Psychology, 12, 264-272.

Manson J.H. (2015). Life history strategy and the HEXACO personality dimensions. Evolutionary Psychology, 13, 48-66.

McAdams D.P., Pals J.L. (2006). A new Big Five: Fundamental principles for an integrative science of personality. American Psychologist, 61, 204-217. 
McAdams D.P., Olson B.D. (2010). Personality development: continuity and change over the life course. Annual Review of Psychology, 61, 517-542.

McCrae R.R., Costa P.T. Jr. (1999). A Five-Factor theory of personality. W: L. Pervin, O. John (eds.), Handbook of Personality: Theory and Research, 139-153. New York: Guilford Press.

McCrae R.R., Costa P.T. Jr. (2004). A contemplated revision of the NEO Five-Factor Inventory. Personality and Individual Differences, 36(3), 587-596.

McCrae R.R., Costa P.T., Ostendorf F., Angleitner A., Hrebícková M., Avia M.D., Smith P.B. (2000). Nature over nurture: temperament, personality, and life span development. Journal of Personality and Social Psychology, 78, 173-86.

Mell H., Safra L., Alganb Y., Baumard N., Chevallier C. (2017). Childhood environmental harshness predicts coordinated health and reproductive strategies: A cross-sectional study of a nationally representative sample from France. Evolution and Human Behavior, 39, 1-8.

Neblett E.W., Hammond W.P., Seaton E., Townsend T.G. (2010). Underlying Mechanisms in the Relationship Between Africentric Worldview and Depressive Symptoms. Journal of Counseling Psychology, 57(1), 105-113. https://doi.org/10.1037/a0017710.

Nettle D. (2005). An evolutionary approach to the extraversion continuum. Evolution and Human Behavior, 26, 363-373.

Nettle D. (2006). The evolution of personality variation in humans and other animals. American Psychologist, 61, 622-631.

Nettle D. (2010). Dying young and living fast: Variation in life history across English neighborhoods. Behavioral Ecology, 21, 387-395.

Nillson A. (2014a). Personality psychology as the integrative study of traits and worldviews. New Ideas in Psychology, 32, 18-32. https://doi.org/10.1016/j.newideapsych.2013.04.008.

Nilsson A. (2014b). A non-reductive science of personality, character, and well-being must take the person's worldview into account. Frontiers in Psychology, 5. doi: 10.3389/fpsyg.2014.00961.

Nudelman G. (2013). The belief in a just world and personality: A meta-analysis. Social Justice Research, $26,105-119$.

Penhollow T., Young M., Denny G. (2005). The impact of religiosity on the sexual behaviors of college students. American Journal of Health Education, 36, 75-83.

Parks-Leduc L., Feldman G., Bardi A. (2015). Personality traits and personal values: a meta-analysis. Personality and Social Psychology Review, 19, 3-29. doi: 10.1177/1088868314538548.

Persson B. (2014). A Study of personality and family and school environment and possible interactional effects in 244 Swedish children: A multiple regression analysis. Psychology, 5, 886-895.

Peterson A., Geher G., Kaufman S.B. (2011). Predicting preferences for sex acts: which traits matter most, and why? Evolutionary Psychology, 9, 371-389.

Poulin M.J., Silver R.C. (2008). World benevolence beliefs and well-being across the life span. Psychology and Aging, 23, 13-23.

Raby K.L., Roisman G.I., Fraley R.C., Simpson J.A. (2015). The enduring predictive significance of early maternal sensitivity: Social and academic competence through age 32 years. Child Development, 86, 695-708. doi: 10.1111/cdev.12325.

Robins R.W., Tracy J.L., Trzesniewski K., Potter J., Gosling S.D. (2001). Personality correlates of self-esteem. Journal of Research in Personality, 35, 463-482.

Roccas S., Sagiv L., Schwartz S.H., Knafo A. (2002). The Big Five personality factors and personal values. Personality and Social Psychology Bulletin, 28, 789-801. http://dx.doi.org/10.1177/0146167202289008.

Rostosky S.S., Wilcox B.L., Wright M.L.C., Randall B.A. (2004). The impact of religiosity on adolescent sexual behavior: A review of the evidence. Journal of Adolescent Research, 19, 677-697.

Rucas S.L., Miller A.A. (2013). Locus of control and sleep in evolutionary perspective. Journal of Social, Evolutionary, and Cultural Psychology, 7, 79-96.

Schmitt D.P., Realo A., Voracek M., Alik J. (2008). Why can't a man be more like a woman? Sex differences in Big Five personality traits across 55 cultures. Journal of Personality and Social Psychology, 94, 168-192.

Schwartz S.H. (1992). Universals in the content and structure of values: Theoretical advances and empirical tests in 20 countries. W: M.P. Zanna (ed.), Advances in Experimental Social Psychology, 1-65. San Diego, CA: Academic Press. 
Sharpe P.J., Martin N.R., Roth K.A. (2011). Optimism and Big Five factors of personality: Beyond neuroticism and extraversion. Personality and Individual Differences, 51, 946-951.

Simpson J.A., Griskevicius V., Kim J.S. (2011). Evolution, life history theory, and personality. W: L.M. Horowitz, S. Strack (eds.), Handbook of Interpersonal Psychology: Theory, Research, Assessment, and Therapeutic Interventions, 75-89. New York, NY: Wiley

Sorokowska A., Słowińska A., Zbieg A., Sorokowski P. (2014). Polska adaptacja testu Ten Item Personality Inventory (TIPI) - TIPI-PL - wersja standardowa i internetowa. Wrocław: WrocLab.

Stearns S.C. (1992). The Evolution of Life Histories. Oxford: Oxford University Press.

Uziel L. (2006). The extraverted and the neurotic glasses are of different colors. Personality and Individual Differences, 41, 745-754.

Watson D., Suls J., Haig J. (2002) Global self-esteem in relation to structural models of personality and affectivity. Journal of Personality and Social Psychology, 83, 185-197.

Wenner C.J., Bianchi J., Figueredo A.J., Rushton J.P., Jacobs W.J. (2013). Life history theory and social deviance: The mediating role of executive function. Intelligence, 41, 102-113.

Wilt J.A., Grubbs J.B., Exline J.J., Pargament K.I. (2016). Personality, religious and spiritual struggles, and well-being. Psychology of Religion and Spirituality, 8, 341-351. http://dx.doi.org/10.1037/rel0000054.

Wojciszke B. (2010). Sprawczość i wspólnotowość. Podstawowe wymiary spostrzegania społecznego. Gdańsk: Gdańskie Wydawnictwo Psychologiczne.

Young E.S., Simpson J.A., Griskevicius V., Huelsnitz C.O., Fleck C. (2017). Childhood attachment and adult personality: A life history perspective. Self and Identity, 18(1), 22-38. doi: 10.1080/15298868.2017.1353540.

van Leeuwen A.J., Mace R. (2016). Life history factors, personality and the social clustering of sexual experience in adolescents. Royal Society Open Science, 3, 160257.

Załuski M., Gajdosz M. (2012). Skala Założeń Wobec Świata. Polska adaptacja i analiza walidacyjna World Assumptions Scale. Psychoterapia, 3, 17-31. 